\title{
Between Zenon and Leda: Notes on Marin Sorescu's Poetry
}

\author{
ENTRE ZENÃO E LEDA: \\ NotAS SOBRE A POESIA DE MARIN SORESCU \\ George Popescu
}

Associação Romena de Escritores/

Bucareste, Romênia

\begin{abstract}
Marin Sorescu is one of the most important Romanian poets of the last half century, being translated into more than 30 languages; he was a complex personality, poet, essayist, playwright, artist, winner of numerous international awards. Our study is an attempt to decode the complex message of his work starting from concepts such as parody and re-writing (of some ancient myths), by means of well-balanced irony between the pressure of a Universal Library and the inquisitive spirit of a poet for whom the original roots of his own culture are landmarks and opportunities to analyze the universe of the contemporary world.
\end{abstract}

\section{Resumo}

Marin Sorescu é um dos mais importantes poetas romenos da segunda metade do século passado. Poeta, ensaista, dramaturgo, artista, tendo sido traduzido para mais de 30 línguas, e recebido vários prêmios internacionais, era uma personalidade complexa. Nosso estudo é uma tentativa de decodificar a difícil mensagem de suas obras, começando com conceitos tais como paródia e reescrita (de alguns mitos antigos), por meio de uma ironia bem balanceada entre a pressão de uma Biblioteca Universal e o espírito investigador de um poeta para quem as raízes originais de sua própria cultura constituem a ocasião e as balizas centrais para analisar o mundo contemporâneo.

\section{Résumé}

Poète, essayiste, dramaturge, artiste, traduit en plus de 30 langues et lauréat de nombreux prix internationaux, Marin Sorescu est l'un des plus importants écrivains roumains de la deuxième moitié du XXe siècle. Notre étude est une tentative de décoder le message complexe de son travail à partir de concepts tels que la parodie et la réécriture (de certains mythes antiques), par le biais d'une ironie bien équilibrée entre la pression d'une bibliothèque universelle et l'esprit curieux d'un poète pour qui les racines originelles de sa propre culture constituent les repères et la possibilité d'analyser le monde contemporain.
Keywords: Marin Sorescu; parody; Romanian poetry.

Palavras-chave: Marin Sorescu; paródia; poesia romena.

Mots-clés: Marin Sorescu; parodie, la poésie roumaine. 
Between the denominative function of language and the ontological condition of the Real, Marin Sorescu ${ }^{1}$ infers the insidious presence of a process initiated, poetically, through a mechanism of substitutions that assumes the appearance of a paradox.

The threshold of translation, namely, the shifting of language into a connotative system, does not imply an effort of metaphysicization; in other words, in the traditional therefore modern way, it does not any longer seek "pure" transcendence of Mallarméan extraction, but an act of postmodern parody of the same real, whose language, playfully reinvested with a denotative function, grows into a correlative kind of subversive.

In what way in Marin Sorescu's poetry does this radical transformation occur at the level of two dissociative layers, namely at the level of Romanian poetry in actu, i.e. the moment of the publication of the volume Poems in 1965, and the moment of his own poetic adventure respectively?

\footnotetext{
${ }^{1}$ Marin Sorescu was born in the village of Bulzesti, county of Dolj, the fifth child of a family of peasants. He attended secondary schools in Craiova and Predeal, graduating from Iasi University in Philology. He worked as editor-in-chief of the literary periodical Ramuri.

His first volume of poetry Singur Printre Poeti (Along Amongst Poets) was published in 1964 , followed by many volumes of poetry, prose and drama.

His first play, Jonah, was published in 1968, followed by The Verger in 1970, and The Matrix in 1973. In 1974 the three were included as a trilogy in The Thirst of the Salt Mountain [...]

His work has been translated into many languages, and his plays performed throughout the world.

In 1974 he was awarded the drama prize by the Writers' Union of Romania, and in 1978 the international prize 'Le Muse' by the Accademia delle Muse in Florence. In 1983 he was made a correspondent member of the Mallarmé Academy in Paris and in December of the same year he received the 'Fernando Riello' International Poetry Prize in Madrid.

In 1964 the Romanian government relaxed its censorship policies, signaling a new openness to freedom of expression. The nation's poets heeded that signal, and Romanian poetry experienced a striking revival. The poet and playwright Marin Sorescu is perhaps one of the most popular figures to emerge from Romanian literary culture in the years since.

Sorescu writes in a plainspoken, down-to-earth style spiced with sly humor. $\mathrm{He}$ responds to the hardships of Romanian life not with grand rhetoric or fire-andbrimstone sermons, but with what his translator Michael Hamburger describes as "ironic verse fables," as quoted by Dennis Deletant in the Times Literary Supplement. Virgil Nemoianu, also writing in the Times Literary Supplement, comments that "[Sorescu's] reactions to an increasingly absurd political regime were always cleverly balanced: he never engaged in the servile praise of leader and party usually required of Romanian poets, nor did he venture into dissidence. He was content to let irony do its job."

His choice of irony over confrontation has made it possible for Sorescu to pub-
} 
Let us revert, with the acquisitions we have made meanwhile, but also with today's detachment, to that moment of Romanian poetry.

We are witnessing the climax of the process of exhaustion of Proletkult poetry, therefore the end of an experience that, noisily and primitively exiling whatever had been achieved in more than a century of Romanian poetry, and especially annulling with reprehensible brutality the whole dramatic inter-war effort of synchronizing our tradition with European literature, initiated by a famous critic such as Eugen Lovinescu, had ended, by now, in ridiculous manner. The attempts of overcoming the crisis take place in the still discreet line of the effort to resume the old patterns of poetic production. The stake, obviously camouflaged within this effort that anticipates and prepares the moment of the so-called thaw ${ }^{2}$ - was to remake the connection with inter-war poetry and reintegrate it into a sort of continuum.

The man Marin Sorescu did not retain anything from the dusty "gallery" of the (actually so false) legend by which a hypocritical tradition insisted on delivering to us the figure of The Poet: he was rather "antipoetic", or an "anti-poet"; actually, the phrase "alone among poets", so lucky for the apparent destiny of its author, preserved, beyond the playful circumstance, a poetic and poietic feature so profound that it still needs to be discerned and interpreted. ${ }^{3}$

lish freely and frequently. The journal he edited for years, Ramuri, managed like his poetry to stay within the bounds expected by the Romanian regime. Sorescu's plays, however, have not always fared as well. Both Jonah and Nerves Do Exist played to packed houses in Bucharest, the former in 1969 and the latter in 1982. But both plays were quickly withdrawn, their content deemed too controversial. Nonetheless, notes Deletant, the success of these plays during their brief runs strengthened "Sorescu's status as one of the leading writers of his generation."

Sorescu's plays and poetry have earned him, Deletant further states, "an unequaled audience" at home in Romania. And translations of his work into English have helped him build a secure international reputation. The qualities that have allowed his writings to flourish on Romania's state-controlled literary scene may contribute to his popularity abroad as well. There is a universality to Sorescu's conversational tone and ironic perspective, what Nemoianu calls "his rueful jocularity and the good-natured cynicism.” George Szirtes, writing in Times Literary Supplement, finds in Sorescu's voice "the wry wisdom that sees through everything and yet continues to hope and despair."

${ }^{2}$ We refer to the first years of the Ceausescu regime (roughly 1965-1971), when the dictator, denouncing the Stalinist type of socialism installed by the Soviet army at the end of the war, strategically adopts a rapprochement to the Western world, suggesting a turning away from Moscow, with the overt intent of assuming a relative independence that will actually provide him with the ideal pretext for installing a personality cult beyond the limits of tragic absurdity.

${ }^{3}$ Alone among poets is the title of the poet's poetic debut in 1964, with parodies 
Rather demure in conversation, extremely suspicious and susceptible to any challenge on poetry and art, he used to play with unconcealed ability the part of the "stutterer" doubled by savour, compulsorily recorded with a guilty delay, never regretted, always illuminated. He was a non-profit anti-confessional kind of person. Generous and available, but only to the inflammatory limit where art turns into an object of disgusting transactions.

Demanding with others, he proved enormously exigent with his own work: writing acquired for him the dimension of an effort that unconditionally implied the mark of a completely assumed bet, always at the limit of survival. Hasty interpreters should keep in mind that this "ordeal" seems exactly the opposite of the "finite" work or of the superficial impression that the author had kept, unfortunately, almost all along his career as a writer who made a modus operandi out of defiance (of conventions, mostly).

Marin Sorescu fought against the word/words with the staunchness with which a gifted artist fights against colours. I watched him ${ }^{4}$ writing, working, rewriting, correcting in a gigantic, often ravaging effort, inexplicably scrupulous, cutting and removing lines that seemed, if not brilliant, at least suitable in the context, sentences whose judgement and profoundness (let alone the personal, Sorescu-branded "style") impressed, lines whose originality of the phrasing shocked, all of which no dramatist would have been ashamed of.

It seemed difficult to assess the mechanism then and there, hard to identify the immediate or remote causes of the discontent that turned the author into an unclassifiable guard of his own texts. Only later, when the work reached a form that evinced not finitude, but a personal, unmistakable mark, did something in the secret motives of this kind of torture reveal some clues. The des-

of false works written by fellow poets in the style of what was at that time called Proletkult, based on propaganda patterns imposed by the Soviet occupation of Romania. In this context, it is worth mentioning the innovative and courageous poetic program promoted by some of the poets of the 1960 Generation, among whom Marin Sorescu himself, by which the resumption of the officially banned Romanian inter-war poetic tradition is subversively achieved. Even more challenging is the new poetics' choice of the Romanian avant-garde of the 30 's and especially of the 40's as its landmark, speculating the fact that its members had been anti-fascist.

${ }^{4}$ Destiny had it that for several years I subedited the literary periodical Ramuri, whose editor-in-chief he was for more than a decade. 
perate search, the insidious torment, the terrifying torture, the prying (the author's favourite term both in writing and in his oral discourse) of an obsessive-obsessing kind articulated an elementary act of hunting something resembling a ghost taking the shape of a reality hidden somewhere beyond names, but on this side of words.

Marin Sorescu was never, as too easily one might have believed, given (once more) the misleading surfaces of his work, either a lucky "manipulator" of words appropriated by parody-like games at hand, or a "constructor" of edifices erected by mere alchemy of a mock mise-en-scene. Sorescu had long ago assumed, since adolescence, almost all the hypostases of his subsequent work. In fact, his boyhood and youth "poetry" notebooks should be looked into sometime; this examination could be twice revealing: one would find out that the author of La Lilieci had cut across, step by step, episode by episode, the whole "story" of Romanian poetry with the virtues of someone who proved, since very young, receptive capacities, an undisputed and almost precocious genius of "already tried", "received" forms; secondly, one may finally record the decisive fact, in my opinion, in understanding Sorescu's work, that the "forms" adopted by the poet at his debut, especially in the volumes that were to follow, were not the signs of an initiation but, on the contrary, emblems of an option assumed at the end of a long and difficult process of trials and, mostly, renunciations (and abandons).

Poetry on the threshold

The major stake of the Sorescian discourse is - and that has been observed too - the effort for authenticity. In fact, this effort (which engages and puts to work, in a fertile manner, the semiotic function of language, the textualizing conscience of the creative act, as well as the process of intertextuality, all these elements finding in the author of Descântoteca/Magic spellotheque the most credible precursor of literary mutations that occurred in our literature over the last three decades) is governed by a movement with an almost indistinct philosophical support. It is a process that involves a double emancipation of the poetic, from myth and, consequently, from itself. It is an answer - an adequate, original one - to the crisis of poetry in the last century, mainly a modernity crisis. The novelty of the Sorescian option is maintained by focusing the act of creation on the second movement, the emancipation of poetry from 
and out of itself. Thus one can better explain the awareness of textualization the intertextualist lode, as well as the mentioned postmodern brackets, but Sorescian poetics may be granted individual marks of its emblematic figure(s).

Here is, somehow randomly taken, a famous poem from world poetry, in which William Shakespeare grows to the dimension of a demiurge, creator of his own, self-sufficient world, the creational act almost liturgically instating a virtually epiphanic discourse:

On the first day he made the sky, the mountains and the depths [of the soul.

On the second day he made rivers, seas, oceans And other emotions...

And he gave them to Hamlet, Julius Caesar, Anthony, Cleopatra

To Othello and others, [and Ophelia,

To be master over them, with their descendants,

For ever and ever.

On the third day he gathered all the people

And taught them to savour:

The taste of happiness, love, despair,

The taste of jealousy, fame and so on,

Until all tasting was finished.

Then some late-comers arrived.

The creator patted their heads with compassion,

Saying the only roles left for them were

The literary critics

Who could then demolish his work.

The fourth and fifth day he reserved for laughter.

He allowed clowns

To tumble,

He allowed kings, emperors

And other unfortunates to amuse themselves.

On the sixth day he completed the administration:

He set up a tempest

He taught King Lear

How to wear a straw crown.

As there were a few leftovers from the creation of the world

He designed Richard III.

On the seventh day he took stock to see what else might be done.

And Shakespeare thought that after so much effort

He deserved to see a performance;

But first, as he was overtired,

He went to die a little

("Shakespeare created the world in seven days") 
A parody of the existent, of poetry, of Literature, "exhibit-like" objects that had not passed yet into the canonized lyrical inventory are, by now, current assertions of the exegetics of the Sorescian poetics of that moment, and even of a subsequent period. Critical judgments, far from being untrue, contribute (sometimes voluntarily, but often involuntarily) to a vitiated reception of the author's poetry or at least to its jamming: they painstakingly extract, with the explosion of "discovery" at hand, impulses ready-served by poetry itself, and offers them to the reader in the guise of rough drafts with the function of recipes.

Furthermore, they reproached the poet for the danger of imitation, of mannerism, and even more seriously, of self-pastiche; all these were, certainly, almost commonplace in the author's poetry, but they ignored their "methodical" invocation and usage, employed by the author as a possible ostentatious answer to the state of crisis itself felt by the literary genre as such. What seems to have mostly hindered the exact positioning of the undertaking of the author of Death of the clock was precisely the apparent yet false impression that the answers were nothing but momentary handy "solutions", simple "job offers".

In reality, the poet's offers-answers weren't solutions (compromised beforehand, as long as the crisis had to be lived to the end, as in a famous formula of Nietzsche-Heidegger), but desperate modes of saving whatever could be saved from the disaster that had weakened language to its last link.

Sorescu himself had identified a weak link (not the Montalian, exhausted link - che non tiene-, although this one may also be invoked, albeit not from an ontological perspective, but from a poietic one), but the one that had turned poetic language into a kind of unpleasant feast. Of course, the whole bet of the poem is the "methodically" used appeal to metonymy, like a photographic filter installing an innovatory semantic suggestion: the words, lent to their zone of common use, assumed as non- or anti-poetic, acquire an overt subversive, insurrectional function; literary critics hastened to signalize the de-canonizing function of metonymy, the playful (surface) spirit that changes the morganatic aspect instituted by the "old" poetry, undoes the solemnity and sacrality, not of the poem, but of the pattern itself of poetry "making". Exact, pertinent assertions, yet not sufficient to delineate the authentic innovatory spirit that governs the entire Sorescian approach of the period. 
In Sorescu's representation of the act of creation, a constituent of life, poetry is neither a "mirror" (we are far from the Romantic specularity), nor a repulsive addition to the stylized existence at the level of a "trace" with an ontic valence, but a sort of infra-discourse within the very lymph of vitality, imperatively claiming the spectrum and cross of a destiny tried by the prophecy of suffering like a resuscitation of crucifixion whose salvation appears only like a useless supposition:

I'm being visited more and more seldom

By respiration.

I can't breathe anymore - so I can't write therefore, I live no more.

And here I ask:

The portion of my air I did not breathe

(Since I was gone before the deadline)

Is it worth anything?

At least it could be given to the poor

(If this were possible)

But this is such an absurd parsimony

Of Nothingness.

And further on:

The thoughts I left unwritten

By whom will they be finished? Since grains of sand are not alike

How could a new pen different from mine

Resume the thread exactly from the point I ceased?

And I had just discovered

A handful of great subjects, themes.

I had already improvised - and it did work - my style

Who is the one who will decode my notes

Which I could never organize?

Is it then you who will give answer

To these simple, common sense questions

You Pure Nothingness?

("The Scribe")

Something happened with Sorescu's poetry (but also with his plays, essays, and criticism) that did not have the expected and deserved echo in exegetics: the reception of his work by a reader turned into spectator. And it was not, as it was often thought out of convenience rather than malice or misunderstanding, a momentary or circumstantial success: it was not the "form" of poetry, not even the much invoked pointillism, that carried exclusively - not at all 
essentially - the responsibility of this success, but something more profound, something located in the inner dialectics of the Sorescian discourse. Maybe even what we called the powerful emancipation of the poetic to the second power, actually a circular movement, including the hermeneutic sense assumed from Dilthey onwards.

The poet discloses, "philosophically" speaking, the reification process of human nature; the "objectification" of the human being is, at first, a denouncement of the "modern" world, on the way to lose touch with the essential. A recurrent "subject" in contemporary culture, handy, not lacking a slight taste of trifling. It so happens that such tough "subjects" are, more often than not, "attacked" by rhymesters who, be they in poetry's waiting room or lacking a clear and firm awareness of it, may imagine, out of a representation counterfeited from the start, that the poem needs a "neural network" of ideas (or an ideological one, in the etymological sense of the word) in order to reach the poetic horizon. The assertion is equally valid for the most part of the poetry homologated in a certain period, out of various interests and with extra-aesthetic criteria.

Besides, at the time of his debut, and after the first volumes of the author of The Youth of Don Quixote, his poetry excelled in an awkward placement of the lyrical subject in relation with language and with its function of knowledge: thought as an open process of discursive knowledge, it interfered in the narrative and ended in tautology and simplicity, if not in utterly preposterous ideas. And I do not refer to Proletkult poetry alone, whose aesthetic claims Sorescu and his generation had to avoid from the inside, but even to the inter-war lyrical model, towards which the "new" poets found themselves in an ambivalent attitude, difficult to overcome: they had to resume, on the one hand, the discourse abusively interrupted in the 1960's by extra-literary intrusions and, on the other hand, to break away from it, often in a silent manner, resisting the pressure of a reader eager to see this relation with the initial pattern restored, as Nichita Stănescu once said.

Sorescu had chosen, as it is known, an unconfirmed way until then in the Romanian lyrical praxis: his debut with the parodies Alone among Poets had offered the opportunity - to him, but also to the "new" poetics that was being configured at that time (due to the changes occurred in a history that seemed to reopen to aesthetics) - to perform, in his own way, a kind of tabula rasa with tradition and its derelictness and, on this basis, to prepare in vitro 
a personal model; on the other hand, a fact that was also remarked, he used second-level models (Topârceanu, Minulescu, etc.), thus avoiding the recurrence of models of the hard kind, but no less dangerous from the perspective of the chance of total renewal and of redistribution of accents, according to the new challenges of a reader suddenly interested in the metamorphoses of world poetry.

However, what was not retained with necessary, but rather hypothetical discernment, was the connection between Sorescian poetics and one particular model of the avant-garde. Sorescu, perhaps not lastly, was from the beginning a follower of Urmuz in his early period, and of Tzara as well, from where derives his so frequently invoked influence from Prévert, which remains only a point of convergence, a landmark on the way, on a way of his own, determinedly mapped out from the start, with decisiveness and with a certain form of pride of the man who arrived at the show somehow from outside, but who had proposed, first of all, to know well its rules and canons.

Regardful of the metamorphic relations between logos and mythos, the contemporary Italian philosopher Sergio Givone writes that, faced with the crisis, poetry cuts loose out of myth, cutting itself loose out of its own Self. But the myth is the Self, the substance, poetry's profound content, and poetry cannot be anything else but emancipation, nothing else but the act of emerging out of itself, through a reflex of self-defense, in order to contemplate and self-contemplate.

Poetry is therefore a passage from myth to logos, but this passage assumes the form of interrogation, which is precisely a reality of the myth form. The myth as interrogation means resuming from the start a "narration" that suspended all its referential functions, a fabulous invention without beginning and without ending, lacking the justifying checkout. Essentially it is about a fall, not inside metaphysics, as philosophers of Nietzschean parentage believe, but inside poetry, only where poetry works against myth and meets it again, and at the same time annuls it by reinventing it.

\footnotetext{
${ }^{5}$ Urmuz is a quite special case of Romanian literature and, to a large extent, of world literature: a magistrate in Bucharest in the first two decades of the 20th century, he writes, on his own, ultra-avant-garde texts, but outside any kind of influences or fashions in actu, of which he was not aware. His writings were discovered after he committed suicide in a park; thus his literary experiences forego the Dadaism of his co-national Tristan Tzara, and Eugen Ionescu acknowledged Urmuz as his only master.
} 
In an article written in the 1940's, W. Nestle remarked the evolution (the "fall", some literary historians hurried to decree) of Hellenic poetry from epic to tragedy, and from it to comedy, namely to "satirical drama"; as if language, exhausting its sacredness, had turned towards its own precariousness, substituting the founding pathos with the derisory and with the festal play. Myth decayed, turned into logos, adopting koiné, which is no longer only standardized, current speech, but a form of discourse of the "crowd".

Reverting to the poem Viziune/Vision, let us remark the way in which the poet, recording the effect of reification process of the world, at the end of which he settles, does not pathetically deplore its emergence in the terms of tragedy but, through the grid of irony, parodies its presence under the form of a "feast" only outwardly innocent. It is an anticipation of the cycle La Lilieci, where the centre of the world, the axis mundi of a community that relies on language in their survival attempt, moves from Iocan's clearing to... the grave. It is the answer, defiant in its turn, to the great challenge of late modernity (mainly in our country), it is the skillful way of Marin Sorescu's inquisitive, rebellious spirit of transforming language into a sort of puzzle game in Wittgensteinian manner.

The dismantlement of the mythical and the carnivalization of the world

In a poem such as $\hat{I n}$ dungă/Sideways, the installing process of the Text becomes symptomatic for Sorescu's poetry: we witness, at first, an act of dismantlement of the "sacred", meaning the serious, "romantic" manner (they accurately spoke about a de-romanticizing of poetry in Sorescu's case), an act followed almost concomitantly by another, almost perceptible one, which I would call carnivalization of the world. Everything is, of course, ironical and parodic at the same time:

La început nu era în picioare / Nici un munte, nici un vis. / Aşa că nici ploaia n-avea rost / Să cadă de sus...

In the beginning nothing wasstanding / Neither mountains, nor dreams I So it made no sense / For the rain the fall from above...

The subjacent, so-called subtextual gesture is "mimetic", in the religious meaning of the term, of the type Imitatio Christi; it is, actually, an Imitatio mundi, like many other poems of the author, conceived on the pattern of myth deflagration, starting with the 
cited poems Trebuiau să poarte un nume/The had to have a name and Shakespeare.

The insurgent Sorescian spirit (much more obvious and corrosive in his plays) does not install itself on a primal, genesis-like level, but on a secondary one, because it takes as object of its subversive act Literature itself (its making) or, more precisely, Literariness which it does not compromise, but rescues by submitting it to the carnivalizing action.

Playing with identity is pushed beyond the limit of the absurd, in a game in which the rule of otherness is vitiated until every difference is annihilated, and thus the vital flow becomes a kind of "natural" emergence, like in a famous Ionesco play:

They had been living long together,

And they had rather started to repeat themselves:

He was she,

And she was he.

She was she,

And he was she too.

Sometimes she either was, or she was not,

That's when he was one she, two shes, and many shes.

Such used to be life, more or less.

And above all, early each morning,

Till they would get at last to demarcate

Who was each one,

Where they did start and end

Why in this way and not the other one,

A lot of time was wasted,

As carried by a river time was flowing.

They even tried to kiss sometimes,

But suddenly they realized

That both of them were she.

Much easier to duplicate.

But scared by such discovery,

Both would start yawning

A yawn of softened wool,

Which could be even knitted, the way it follows:

One she yawned very attentively,

Meanwhile, the other she was due to hold the ball.

("Group") 
Sorescian lyricism carries in itself - I should say, written in its own programmatic raison d'être - a spring and a motive of a strong exegetic nature: the spirit that animates it is one of a hermeneutical nature; the poet refuses the descriptive as well as discursiveness (wasn't this very refusal the stake of his debut parodies?), and ironically re-interprets any kind of mythical lode that presses and pries into our imaginary museum, bringing it to the level of daily occurrence.

Sorescu's poetry often dons the form of a Lamentatio Doctoris Fausti, mentioned, if I am not mistaken, by Adorno, but which, for the poet of La Lilieci, became a sort of Lamentatio Doctoris Nastratini. Sorescu's cosmos is a post-Dedalus and a post-Icarus one: all adventures, attempts, founding exploits have been consumed, the World has exhausted all its chances, all its myth-related solutions, the cloakroom of genesis is empty, and what is left for us is travesty and caricature. The word itself has been robbed of any founding function, accepting as a petty remedy a carnivalesque play, not in its "Venetian" version, but in a Byzantine or even a Levantine one.

Here one may identify and explain the model-creating contribution of Sorescu's poetry to the account of recent literary generations, as well as his singular success at a world level. But Sorescu's exegetics is only at the beginning. His work, not only prodigious, but also organically articulated, and especially multifaceted, keeps defying us.

George Popescu é poeta, crítico e tradutor. Membro da Associação Romena de Escritores, publicou diversos volumes de poesia, incluindo Caligrafia silenciosa, no Brasil. Dentre seus numerosos livros de ensaios destacam-se The Mechanics of The Shape; Critical Exemptions. Dissociative Outlooks in Romanian Literature; e Lucian Blaga and the European Paradigm of Thinking. Seus artigos saíram publicados em revistas como Paradigma, Ramuri, Mozaicul, Viaţa Românească, Poesia Sempre, Mosaico (Brazil), Lettre Internationale. 